\title{
ArcheoSciences
}

Revue d'archéométrie

\section{Analytical study of the manufacturing techniques of Kushan gold jewellery (National Museum of Antiquities of Tajikistan)}

Étude analytique des techniques d'orfèvrerie Kouchane (musée national des

Antiquités du Tadjikistan)

Maria Filomena Guerra, Guy Demortier, Maria Luisa Vitobello, Saidmurod Bobomulloev, Dominique Bagault, Thierry Borel and Ikhom Mirsaidov

\section{OpenEdition}

\section{Journals}

\section{Electronic version}

URL: https://journals.openedition.org/archeosciences/2184

DOI: 10.4000/archeosciences.2184

ISBN: 978-2-7535-1598-7

ISSN: 2104-3728

\section{Publisher}

Presses universitaires de Rennes

\section{Printed version}

Date of publication: 31 December 2009

Number of pages: 177-185

ISBN: 978-2-7535-1181-1

ISSN: 1960-1360

\section{Electronic reference}

Maria Filomena Guerra, Guy Demortier, Maria Luisa Vitobello, Saidmurod Bobomulloev, Dominique Bagault, Thierry Borel and Ikhom Mirsaidov, "Analytical study of the manufacturing techniques of Kushan gold jewellery (National Museum of Antiquities of Tajikistan)", ArcheoSciences [Online], 33 | 2009, Online since 10 December 2012, connection on 28 January 2022. URL: http://

journals.openedition.org/archeosciences/2184 ; DOI: https://doi.org/10.4000/archeosciences.2184 


\title{
Analytical study of the manufacturing techniques of Kushan gold jewellery (National Museum of Antiquities of Tajikistan)
}

\author{
Étude analytique des techniques d'orfevrerie Kouchane \\ (musée national des Antiquités du Tadjikistan)
}

\author{
Maria Filomena Guerra*, Guy Demortier**, Maria Luisa Vitobello***, \\ Saidmurod Bobomulloev****, Dominique Bagault*, Thierry Borel* \\ and Ikhom MirSAIDOV*****
}

\begin{abstract}
Little is known about goldsmithing during the period of the Great Kushans. In order to undertake a first approach to the technological choices and the gold alloys used in the fabrication of the different parts of Kushan objects, five gold jewellery items from the collections of the National Museum of Antiquities of Tajikistan containing wires and granulation were transported from Dushanbe to Paris to be studied within the European research project "AUTHENTICO" with non-destructive scientific-based techniques at the C2RMF. All the items were found in archaeological excavations carried out in the 1970s in several regions of Tajikistan and were examined by optical microscopy, scanning microscopy, and X-ray radiography. The compositions of the alloys were determined by ion beam analysis (PIXE) at the AGLAE accelerator.

Résumé : Les techniques orfevres de la période des Grands Koushans sont très méconnues. Afin de décrire les choix techniques de l'orfevre et comprendre le choix des alliages d'or utilisés pour fabriquer des différentes parties constituant les bijoux, cinq objets d'orfevrerie de la période Kouchane, appartenant aux collections du musée National des Antiquités du Tadjikistan, ont été transportés de Douchanbe à Paris, dans le cadre du projet européen "AUTHENTICO", pour être étudiés au C2RMF au moyen de techniques scientifiques non-destructives. Tous les objets proviennent de fouilles archéologiques menées dans les années 1970 dans différentes régions du Tadjikistan. Ils ont été observés par microscopie optique, microscopie électronique et radiographie X. Leur composition a été déterminée par analyse par faisceau d'ions (PIXE) à l'accélérateur AGLAE.
\end{abstract}

Keywords: Kushan, jewellery, analysis, PIXE, gold.

Mots-clés : Koushan, orfevrerie, analyse, PIXE, alliages d'or.

\footnotetext{
* Laboratoire du Centre de Recherche et de Recherche et de Restauration des Musées de France, UMR171 CNRS - 14, quai François-Mitterrand, 75001 Paris,France. (maria.guerra@culture.gouv.fr)

** LARN, University of Namur - 61, Rue de Bruxelles, 5000 Namur, Belgium; Center for Dating and Diagnostics, Department of Engineering of Innovation, Faculty of Cultural Heritage, University of Salento, Lecce, Italy. (guy.demortier@tvcablenet.be)

*** National Museum of Antiquities of Tajikistan, Academic Rajobov - 5, Dushanbe, Tajikistan. (said@ac.tajik.net)

**** EJTN GEIE, European Jewellery Technology Network - 124 rue du Commerce, Brussels, Belgium. (info@ejtn.org)

**** Nuclear and Radiation Safety Agency - 33 Rudaki Avenue, 734025, Dushanbe. (agentilhom@mail.ru)
} 


\section{INTRODUCTION}

The Kushan Empire had its origins in the $2^{\text {nd }}$ century BC, when a confederation of nomadic Indo-European Yuezhi tribes invaded and settled in the Sogdiana and the Bactria areas in Central Asia (Puri, 1999; Rapin, 2007). This branch of the Yuezhi had their origins in north-western China, where they lived until being pushed back by the Xiongnu. The Xiongnu, a pastoral nomadic tribal confederation from the Ordos (Thorley, 1971) who produced a large quantity of gold work (Bunker, 1993), occupied a large territory, from the Yellow River to the North of Siberia. Only Sima Qian (145-86 BC) provides in his Shiji (Record of the Historian) some details about this civilisation and about their military superiority, which allowed them to defeat the Han and become the first powerful empire of the steppes along the Chinese frontier (Sarkhosh Curtis and Stewart, 2007).

The branch of the Yuezhi pushed back by the Xiongnu settled along the Oxus River and in southern Bactria (present day Afghanistan and Tajikistan), but expanded from the $1^{\text {st }}$ to the $4^{\text {th }}$ century $A D$, especially under Kanishka I (early $2^{\text {nd }}$ century AD), to north-western India, Pakistan, Uzbekistan and Afghanistan (Dani et al., 1996). Between the $1^{\text {st }}$ and the $3^{\text {rd }}$ century AD, the Kushan controlled Gandhara, where the main road connecting India with the Silk Road and the Mediterranean Sea ran (Wood, 2002; Thorley, 1971).

The Kushan Empire was marked by a time of intensive development of the economy (Mukhamedjanov, 1994) and culture, with two distinct periods separated by a 'dark age' (Sarianidi, 1980): the downfall of the Greco-Bactrian Kingdom during the middle of the $2^{\text {nd }}$ century $\mathrm{BC}$, and the powerful empire of the Great Kushan in the $1^{\text {st }}-2^{\text {nd }}$ century AD (Dani et al., 1996). Chinese, Iranian and Indian traditions were brought together under the Kushan Empire, but the Greek traditions brought by the conquest of Alexander the Great are also evident in the typology of their art. The objects from Tillya Tepe, including the gold Achaemenid type mountain goat, the aureus of Tiberius, the Mithradates II coin, the intaglios with profiles of Athena and inscriptions in Greek, the Bactrian Aphrodite, the jades from China, the garnets from India and other artefacts illustrate all these influences (Sarianidi, 1980).

Little is known about the different goldsmithing techniques and choices from the period of the Great Kushan Empire (Drevnosti Tadzhikistana, 1985). The aim of this work is to undertake a first approach to this question by studying a few items with known provenances, originating from secure archaeological contexts situated in the most important archaeological regions in Tajikistan (Fig. 1): the Beshkent Valley (Medvedskaya et al., 1975; Sedov, 1979)

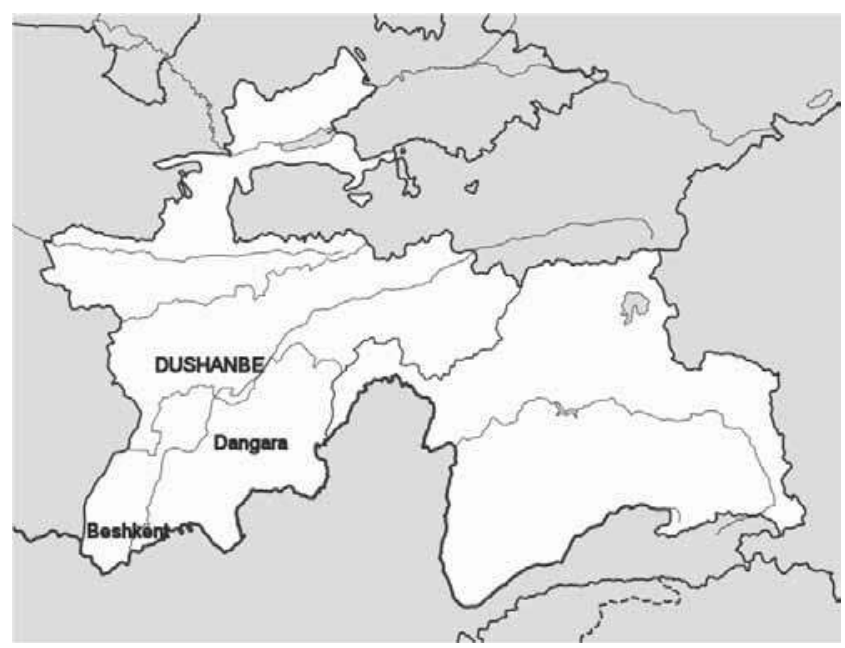

Figure 1: Map of Tajikistan showing the regions of Beshkent and Dangara.

Figure 1: Carte du Tadjikistan avec la localisation des régions de Beshkent et de Dangara.

and the Dangara Valley (Mandelshtam, 1968). Five items found in established excavations, representative of the Kushan jewellery and containing gold wires and granulation, were selected from the collections of the National Museum of Antiquities of Tajikistan (Vitobello et al., 2009). Three of them were found in the Beshkent Valley and are dated to a period between the $1^{\text {st }}$ and the $2^{\text {nd }}$ century AD: an amphora-shaped pendant and a globular openwork pendant, found in the mid 1970s during the excavation of the Beshkent cemetery V (Figs. 2a and 2b); and a cloisonné pendant found in 1978 during the excavation of the Beshkent cemetery VII (Fig. 2c). The pendant earring (Fig. 2d) was found in the late 1970s during the excavation of the Ksirov cemetery III, mortuary enclosure 19, in the Dangara Valley and is dated to a period between the $1^{\text {st }}$ century $\mathrm{BC}$ and the $2^{\text {nd }}$ century AD. Finally, an amphora-shaped earring dated to a period between the $1^{\text {st }}$ and the $2^{\text {nd }}$ century $\mathrm{AD}$ was found in 1973-1974 during the excavation of the "Ittifoq" cemetery in the Parkhar Valley (Fig. 2e).

Within the context of Work Package 5 of the European project AUTHENTICO, the jewellery was transported to the C2RMF in Paris for non-destructive examination by optical microscopy, SEM, and X-radiography (for details on the complementary use of these techniques see Guerra, 2008). The composition of the jewellery was determined by PIXE (particle induced X-ray emission) at the AGLAE accelerator of the C2RMF, with a $3 \mathrm{MeV}$ external proton beam of $50 \mu \mathrm{m}$ diameter and an intensity of 30-40 nA, allowing a depth of analysis which in general is sufficient to avoid the copper depletion. Simultaneous PIGE (particle induced 

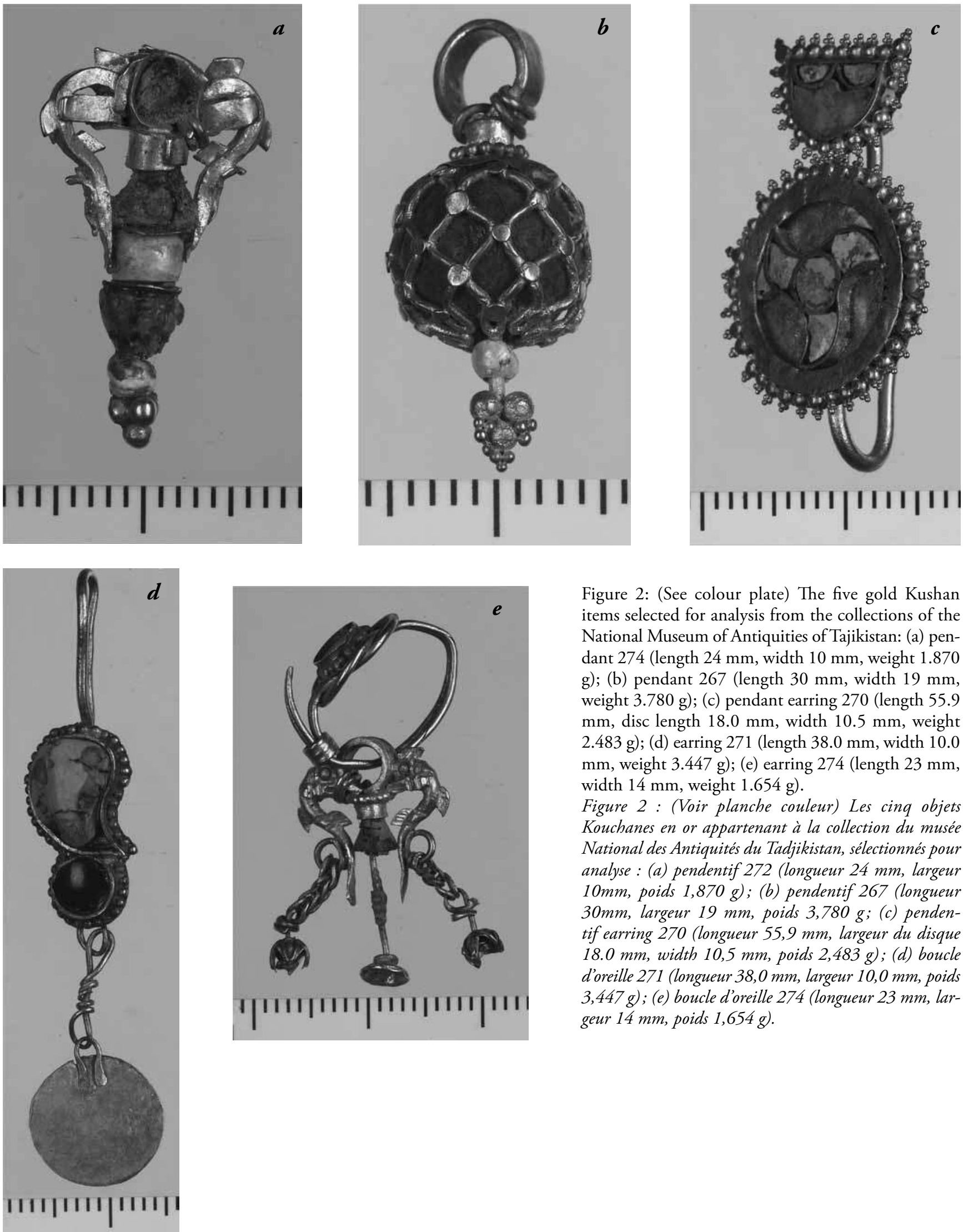

Figure 2: (See colour plate) The five gold Kushan items selected for analysis from the collections of the National Museum of Antiquities of Tajikistan: (a) pendant 274 (length $24 \mathrm{~mm}$, width $10 \mathrm{~mm}$, weight 1.870 g); (b) pendant 267 (length $30 \mathrm{~mm}$, width $19 \mathrm{~mm}$, weight $3.780 \mathrm{~g}$ ); (c) pendant earring 270 (length 55.9 $\mathrm{mm}$, disc length $18.0 \mathrm{~mm}$, width $10.5 \mathrm{~mm}$, weight $2.483 \mathrm{~g}$ ); (d) earring 271 (length $38.0 \mathrm{~mm}$, width 10.0 $\mathrm{mm}$, weight $3.447 \mathrm{~g}$ ); (e) earring 274 (length $23 \mathrm{~mm}$, width $14 \mathrm{~mm}$, weight $1.654 \mathrm{~g}$ ).

Figure 2: (Voir planche couleur) Les cinq objets Kouchanes en or appartenant à la collection du musée National des Antiquités du Tadjikistan, sélectionnés pour analyse: (a) pendentif 272 (longueur $24 \mathrm{~mm}$, largeur $10 \mathrm{~mm}$, poids 1,870 g); (b) pendentif 267 (longueur $30 \mathrm{~mm}$, largeur $19 \mathrm{~mm}$, poids 3,780 g; (c) pendentif earring 270 (longueur 55,9 mm, largeur du disque $18.0 \mathrm{~mm}$, width 10,5 mm, poids 2,483 g); (d) boucle d'oreille 271 (longueur 38,0 mm, largeur 10,0 mm, poids 3,447 g); (e) boucle d'oreille 274 (longueur $23 \mathrm{~mm}$, largeur $14 \mathrm{~mm}$, poids $1,654 \mathrm{~g}$ ). 
gamma-ray emission) was carried out in order to compare the compositions of the deep and surface layers.

\section{TeChNOLOGICAL DESCRIPTION OF THE JEWELLERY ITEMS}

\section{Earring 274}

The amphora-shaped earring reference 274 in Catalogue 1983 and reference 8 of Masov et al. (2005), page 120 (Fig. 2a) is composed of gold strips of about $950 \mu \mathrm{m}$ diameter, bent, folded and joined to produce symmetric handles holding the amphora's body. Two discs of 130-200 $\mu \mathrm{m}$ thickness separate a bead of certainly iron pyrite (this type of decoration is common for Tillya Tepe jewellery, Collectif, 2006) and pearl elements that constitute the body. The top of a rod going through the body is threaded around the amphorass suspension hook and is finished with a pyramid of four large granules of $1650 \mu \mathrm{m}$ diameter.

\section{Pendant 272}

Globular pendant reference 272 in Catalogue 1983, reference 6 of Masov et al. (2005), page 120 (Fig. 2b) consists of an iron pyrite bead covered with an open net birdcage of $500 \mu \mathrm{m}$ diameter strip-twisted wires bent to form loops at the bottoms (Fig. 3). The junction points of the wires are ornate with small plain discs of $800 \mu \mathrm{m}$ diameter. A suspension solid gold ring is joined to a strip of gold folded into a narrow cylindrical shape surrounded by a ringlet of granules of $650 \mu \mathrm{m}$ diameter. These elements are joined to a disc. No solder is visible and a scan carried out by PIXE did not detect the presence of an alloy with different contents of $\mathrm{Cu}$ or/and $\mathrm{Ag}$; however, the morphology of the joins corresponds to the use of hard soldering. A rod with seams running longitudinally along the wire (morphologically similar to the wires from pendant MK01.40.109 of Tillya Tepe, as discussed by Ogden, 2007) goes through the bead, is coiled around the lower half of the loop, and is completed with a pyramid of four granules of $1450 \mu \mathrm{m}$ diameter. Additional smaller pyramids formed with granules of $650 \mu \mathrm{m}$ diameter are hard-soldered to the top of each larger granule.

\section{Pendant 267}

Pendant reference 267 in Catalogue 1983 and reference 4 of Masov et al. (2005), page 120 (Fig. 2c) consists of one disc and one half-disc in cloisonné inlaid with turquoise and glass paste (identified by visual observation), bordered with
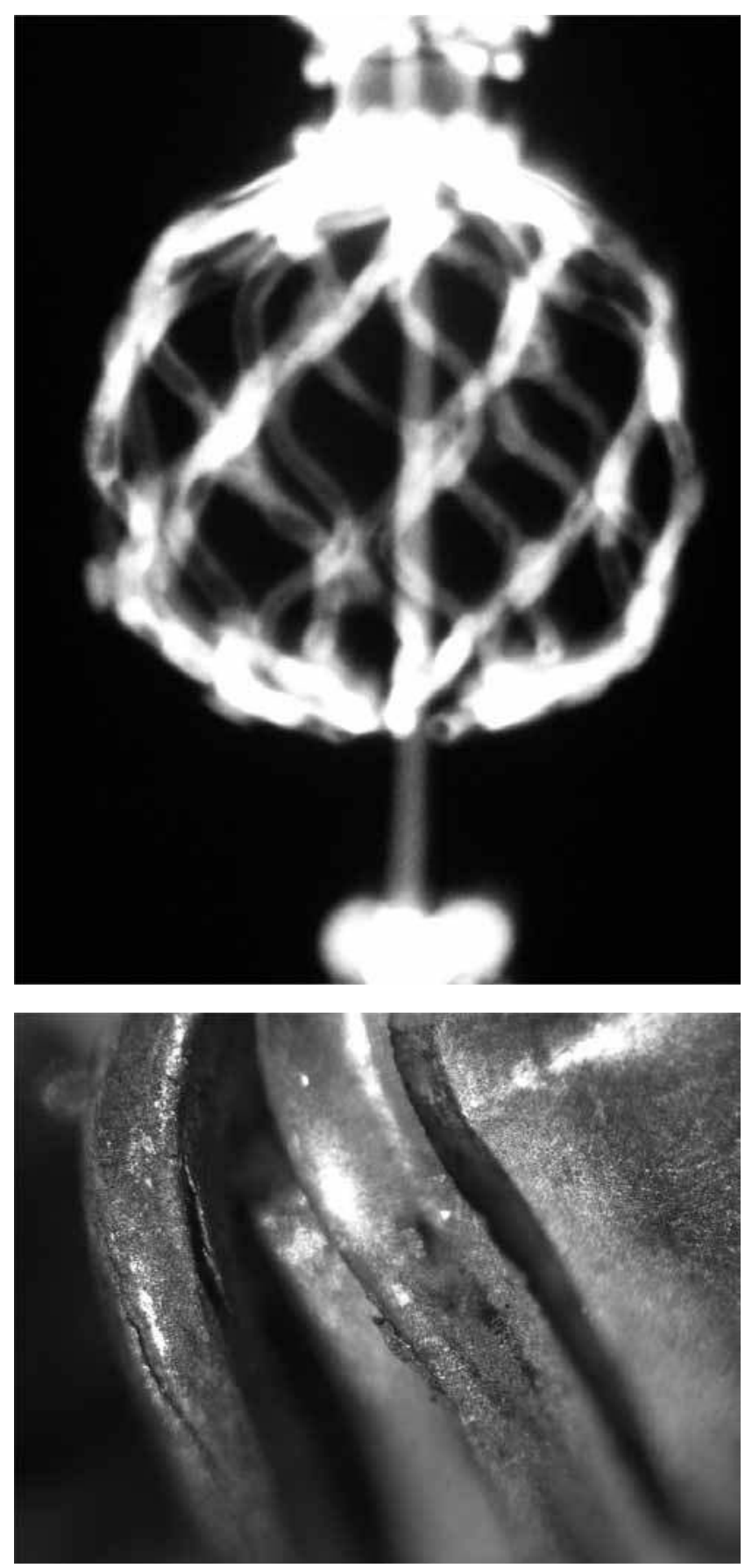

Figure 3: The X-radiography shows that all the wires from pendant 272 , as well as the sustaining rod that goes through the pendant, are hollow. The top of the rod is coiled around the suspension ring. Under the stereo microscope, the seams on the wires appear typical of strip-twisting.

Figure 3 : La radiographie à rayons $X$ montre que tous les fils $d u$ pendentif 272 sont creux ainsi que la tige de soutien qui traverse le pendentif. La tige est ensuite enroulée autour de l'anneau de suspension. La morphologie de surface des filigranes sous loupe binoculaire montre les traces typiques des fils creux tordus. 
granulated pyramids. The cloisons are $300-400 \mu \mathrm{m}$ thick, and the encircling cloison about $2 \mathrm{~mm}$ large (Fig. 4). A $1500 \mu \mathrm{m}$ rod shaped by hammering is bent as a hook and is joined to the back-plate of both elements, holding them together. An additional hook is joined to the back of the half-disc. One end of the hook was flattened while the other end was sharply cut straight.

The outer borders of the setting boxes are surrounded by a row of granules of $1200 \mu \mathrm{m}$ diameter topped by a tiny pyramid of four granules of $400 \mu \mathrm{m}$ diameter on average (Fig. 4). The entire front part of the pendant was flattened, partially damaging a large number of granules.

\section{Pendant earring 270}

Pendant earring reference 270 in Catalogue 1983 and reference 17 of Masov et al. 2005, page 124 (Fig. 2d) is typologically very similar to many objects from Tillya Tepe (Collectif, 2006). A long rod about $1000 \mu \mathrm{m}$ in diameter, forged as a hook and serving as suspension loop and ear hook, is flattened to be joined to the central body (Fig. 5), consisting of one mango-shaped turquoise setting and one round-shaped garnet setting, both in cabochon, placed on the same back plate. Two gold strips, $2 \mathrm{~mm}$ large, form the box settings, which are surrounded by a row of granules about $1 \mathrm{~mm}$ in diameter (Fig. 5). A hammered disc is suspended with a $450 \mu \mathrm{m}$ diameter coiled strip-twisted wire from the main body through a small ring made from a $750 \mu \mathrm{m}$ diameter strip-twisted wire.

\section{Earring 271}

Earring reference 271 in Catalogue 1983 and reference 8 of Masov et al. (2005), page 124 (Fig. 2e), is composed of a suspension hook and a complex pendant. The suspension hook consists of strip-twisted wire of uniform $750 \mu \mathrm{m}$ circular section, each strip bent into a loop, interlocking facing opposite directions, resulting in a Gordian knot that supports a turquoise setting in cabochon surrounded by $700 \mu \mathrm{m}$ diameter granules. These granules are half-melted, maybe because of a poor control of the joining process. On the back side of the hook, one set of $500 \mu \mathrm{m}$ diameter striptwisted wires (Fig. 6a) is joined on the inside of a cylindrical hinge $1000 \mu \mathrm{m}$ large, while the other set of wires is inserted into the same cylinder, emerging for threading into the earlobe. A ring surrounded by one $850 \mu \mathrm{m}$ diameter spooled wire is joined to the two dolphin-shaped handles decorated by chiselling and to the golden amphora's neck. This type of wire is almost absent from Afghani gold work (Ogden, 2007). A strip-twisted wire is wound around the upper part
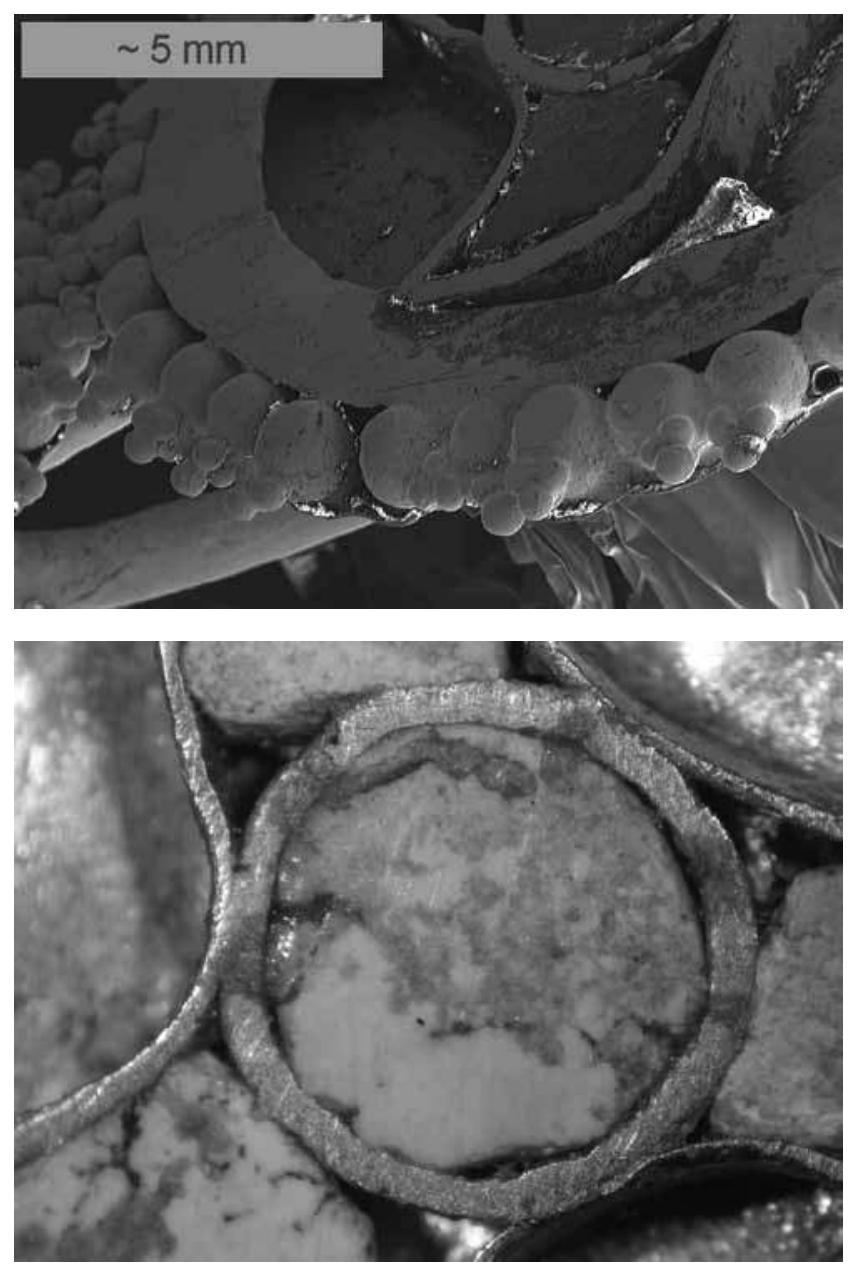

Figure 4: Pendant 267: at the top, detail of the granules under the SEM; below, detail of the cloisonné under the stereomicroscope. Figure 4 : Pendentif 267 : en haut, détail des granules au MEB et en bas, détail du cloisonné sous loupe binoculaire.

of the neck from where the amphora hangs. A coiled striptwisted wire joins the amphora to the ring, functioning as a central rod. At its bottom hangs a flower-shaped bell on 100 $\mu \mathrm{m}$ thick gold foil, decorated with $500 \mu \mathrm{m}$ diameter twisted and spooled wires (Oddy, 1977 definition), as illustrated in Figure 6b. Two suspension rings are joined to the external side of the dolphins' tails, hanging a single loop-in-loop chain of $500 \mu \mathrm{m}$ diameter strip-twisted wire; each chain is obtained by inserting four links into each other. A flowershaped bell decorated with $500 \mu \mathrm{m}$ diameter strip-twisted wires is suspended at the bottom of a coiled strip-twisted wire (Fig. 6c).

ArCheoSCiences, revue d'archéométrie, 33, 2009, p. 177-185 

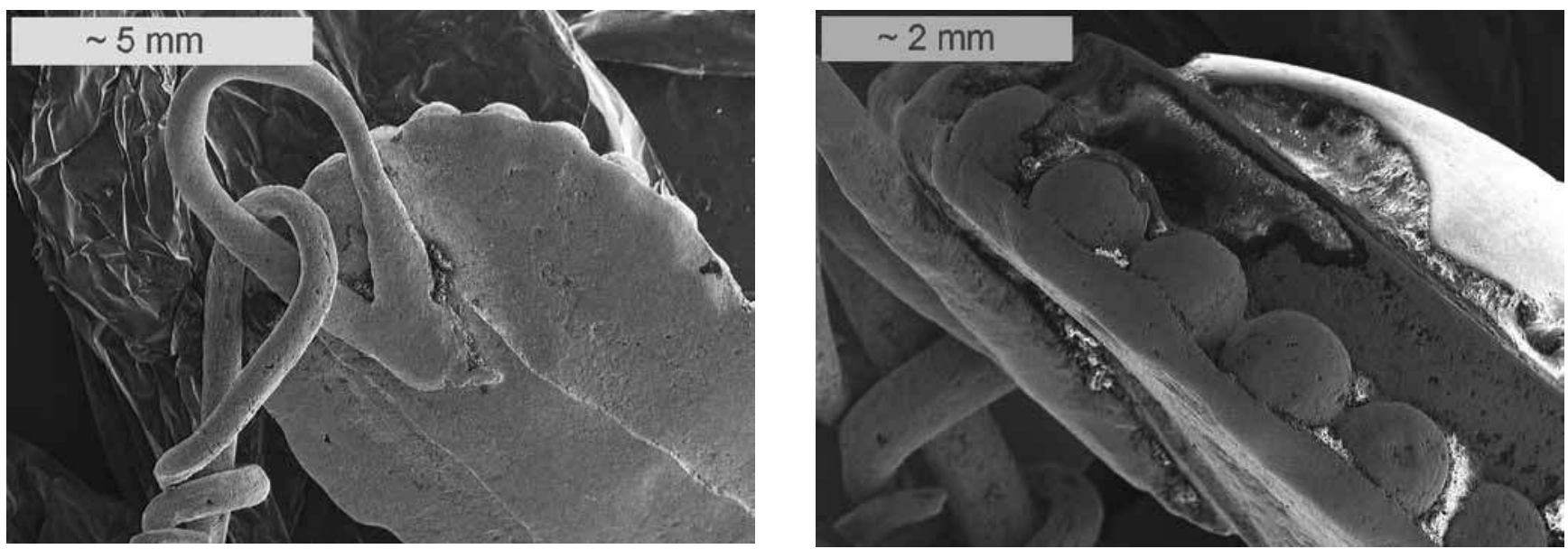

Figure 5: SEM images showing details of earring 270: on the left, the suspension ring, the coiled wire, and the back plate; on the right, the settings box and the granulation.

Figure 5: Les images MEB montrent différents détails de la boucle d'oreille 270 : à gauche l'anneau de suspension, les fils torsadés et la plaque de soutien; à droite la boîte et la granulation.
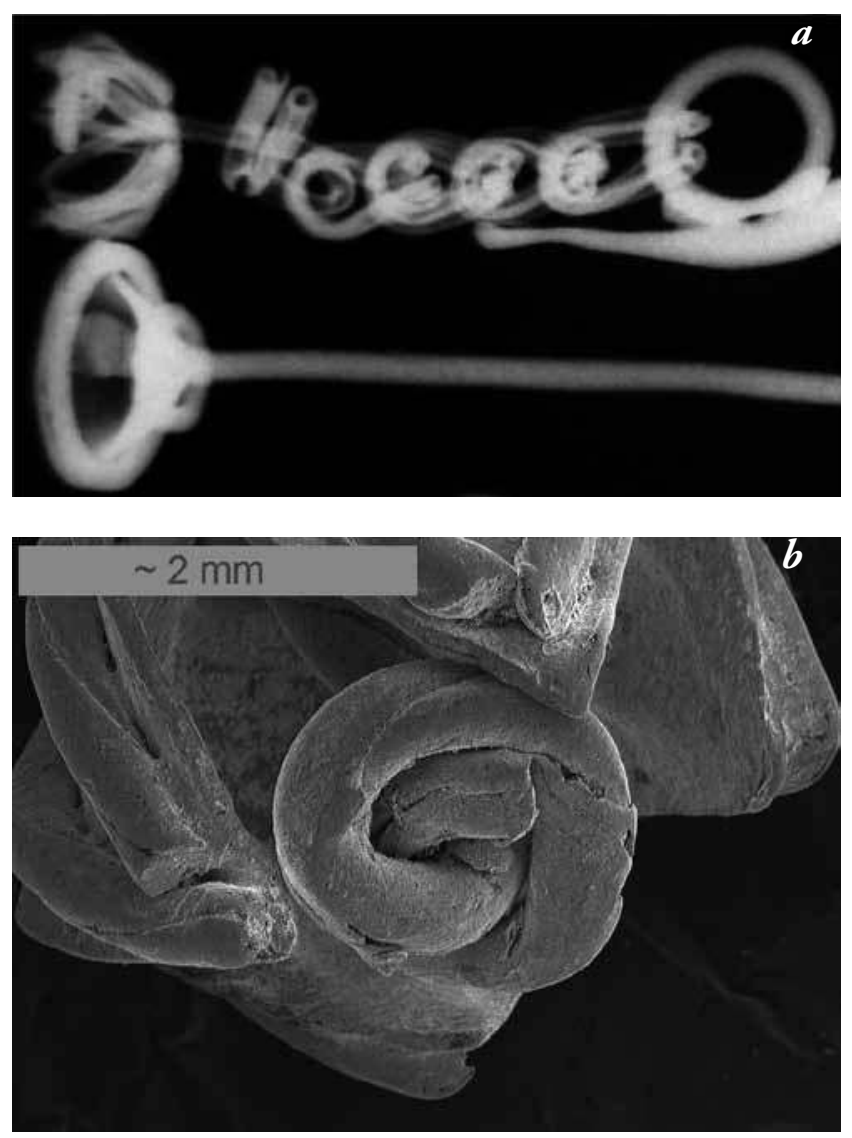

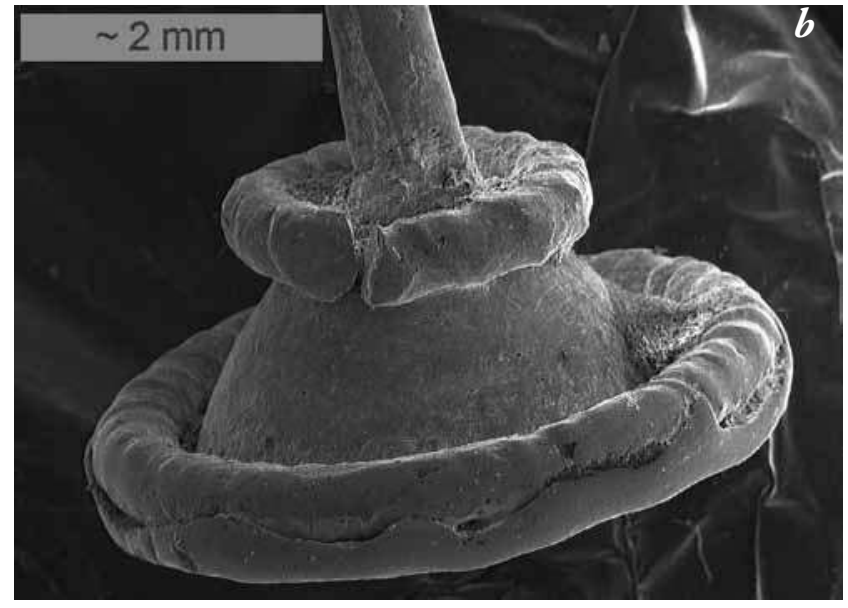

Figure 6: Earring 271: (a) the X-radiography shows that the wires are hollow; (b) and (c) the different wires used in the decoration under the SEM.

Figure 6 : Pendant d'oreille 271 : (a) la radiographie $X$ montre que les fils sont creux; (b) et (c) au MEB les différents fils utilisés dans les motifs de décoration.

\section{THE GOLD ALLOYS}

The composition of the different parts of each jewellery item was determined by PIXE at the AGLAE accelerator of the C2RMF, with a $3 \mathrm{MeV}$ external proton beam of $50 \mu \mathrm{m}$ diameter and an intensity of 30-40 nA. The acquisition times ranged from 3 to 5 minutes. For the bigger parts, a region of $200 \times 200 \mu \mathrm{m}$ was scanned for homogenization. 
Two $\mathrm{Si}(\mathrm{Li})$ detectors were used to collect the X-rays emitted by the sample. One of the detectors is dedicated to the measurement of major elements, while the second detector, equipped with a $75 \mu \mathrm{m} \mathrm{Cu}$ filter to selectively decrease the intensity of the gold L-lines, can be used to identify minor and trace elements when higher acquisition times are used (Guerra, 2004; Guerra and Calligaro, 2004). The compositions of the different parts of the items are presented in Table 1 . The limits of detection are on average $40 \mathrm{ppm}$ for $\mathrm{Cu}, 300 \mathrm{ppm}$ for $\mathrm{Ag}$ and $400 \mathrm{ppm}$ for Au.

The alloys used to fabricate pendant 267 have the following average composition: $82.0 \pm 1.2 \% \mathrm{Au}, 14.7 \pm 1.0 \% \mathrm{Ag}$, $3.1 \pm 1.1 \% \mathrm{Cu}$. These alloys are of better quality than those used in the production of the other four objects, which have the following average composition: $75.2 \pm 2.5 \% \mathrm{Au}$, $22.7 \pm 2.6 \% \mathrm{Ag}, 1.9 \pm 0.8 \% \mathrm{Cu}$. We must however note the slightly higher copper contents of some decorative elements of the disc of pendant 267 as compared to the elements of the half-disc.

The compositions of pendant 272 and earring 271 are very similar; the average composition is the following: $76.3 \pm 2.1 \% \mathrm{Au}, 21.8 \pm 2.3 \% \mathrm{Ag}, 1.7 \pm 0.8 \% \mathrm{Cu}$. However, the granules of the dome plaque of pendant 272 have higher copper contents than the other elements of this item, and some elements have lower silver contents, such as the granules and the junction disc. The back plaques of earring 271 also present higher copper contents than the other elements of this item.

Very few publications consider scientific analyses carried out on Kushan gold objects. However, the analysis of a few Kushan coins, of a gold pendant with garnets, and of a gold coin struck by Kanishka (Sachs et al., 2003) showed the use of gold alloys with compositions which are rather far from our results. The results obtained for the gold alloys used in the fabrication of the Kushan jewellery pieces analysed in this work are also distinct from the compositions found for several gold objects and decoration gold foils from a Xiongnu necropolis, which are separated in two main groups, with silver and copper contents of respectively $2 \%$ and $<1 \%$ for one group and $-10 \%$ and $1-2 \%$ for the other group (Guerra et al., 2005, Guerra and Calligaro, 2003). However, our results are very similar to the composition of the alloys used under Vasudeva II (after circa 261 AD) to strike concave dinars (Fussman, 2003).

As previously noted, the pendant earring 270 is typologically very similar to several objects from Tillya Tepe. A very small set of objects from this necropolis was analysed at the C2RMF, and the results were published by Calligaro (2006). In contrast to the Kushan jewellery analysed in this work, all the analysed objects from Tillya Tepe are of very good

\begin{tabular}{|c|c|c|c|}
\hline & $\mathrm{Cu} \%$ & $\mathrm{Ag} \%$ & $\mathrm{Au} \%$ \\
\hline \multicolumn{4}{|l|}{ Earring 274} \\
\hline \multirow{2}{*}{ strip } & 2.8 & 21.7 & 75.4 \\
\hline & 2.7 & 20.6 & 76.5 \\
\hline central rod & 1.8 & 22.6 & 75.5 \\
\hline cylinder & 2.2 & 21.3 & 75.7 \\
\hline \multirow{2}{*}{ granule } & 2.4 & 21.0 & 76.5 \\
\hline & 2.1 & 21.7 & 76.2 \\
\hline \multicolumn{4}{|l|}{ Pendant 272} \\
\hline suspension hoop & 1.9 & 22.3 & 75.7 \\
\hline \multirow{2}{*}{ dome plaque } & 1.1 & 23.2 & 75.4 \\
\hline & 1.1 & 25.0 & 73.6 \\
\hline \multirow{2}{*}{ dome granule } & 4.0 & 19.0 & 76.7 \\
\hline & 4.0 & 18.9 & 76.8 \\
\hline \multirow{3}{*}{ wire } & 1.2 & 22.3 & 76.4 \\
\hline & 1.1 & 23.1 & 75.7 \\
\hline & 1.1 & 22.0 & 76.9 \\
\hline \multirow{2}{*}{ junction disc } & 1.6 & 19.2 & 79.1 \\
\hline & 1.8 & 18.7 & 79.4 \\
\hline \multirow{2}{*}{ pyramid big granule } & 1.4 & 23.8 & 74.7 \\
\hline & 1.4 & 23.5 & 74.9 \\
\hline \multirow{2}{*}{ pyramid small granule } & 1.5 & 19.2 & 79.1 \\
\hline & 2.0 & 18.6 & 79.3 \\
\hline ring & 1.8 & 26.2 & 71.9 \\
\hline \multicolumn{4}{|l|}{ Pendant 267} \\
\hline \multirow{2}{*}{ disc front plate } & 4.7 & 14.7 & 80.6 \\
\hline & 3.6 & 16.1 & 80.2 \\
\hline disc back plate & 5.9 & 13.1 & 80.9 \\
\hline \multirow{2}{*}{ disc big granule } & 3.0 & 16.1 & 80.6 \\
\hline & 2.2 & 15.8 & 82.0 \\
\hline disc small granule & 3.2 & 15.8 & 81.0 \\
\hline \multirow{2}{*}{ disc cloisonné } & 2.7 & 14.3 & 82.6 \\
\hline & 3.0 & 13.9 & 82.9 \\
\hline \multirow{2}{*}{ half-disc cup cloisonné } & 2.5 & 13.6 & 83.4 \\
\hline & 2.3 & 15.0 & 82.5 \\
\hline half-disc cup external strip & 2.7 & 14.2 & 83.0 \\
\hline half-disc cup back plate & 2.5 & 13.5 & 83.8 \\
\hline Hook & 2.0 & 15.3 & 82.4 \\
\hline \multicolumn{4}{|l|}{ Earring 274} \\
\hline \multirow{2}{*}{ disc } & 1.6 & 27.2 & 70.8 \\
\hline & 1.5 & 27.7 & 70.3 \\
\hline hoop & 1.1 & 29.1 & 69.1 \\
\hline \multirow{2}{*}{ suspension wire } & 2.1 & 24.6 & 73.1 \\
\hline & 2.1 & 24.7 & 73.0 \\
\hline mango box & 2.8 & 23.5 & 73.4 \\
\hline mango box & 2.8 & 20.9 & 75.3 \\
\hline garnet box wire & 2.7 & 25.2 & 72.0 \\
\hline garnet box & 2.3 & 24.7 & 72.6 \\
\hline garnet box granule & 2.4 & 25.4 & 72.1 \\
\hline Earring 271 & & & \\
\hline right pendant plaque & 2.7 & 20.2 & 76.9 \\
\hline right pendant decoration wire & 1.3 & 22.2 & 76.4 \\
\hline right pendant suspension wire & 0.9 & 26.2 & 72.3 \\
\hline left pendant plaque & 2.6 & 22.8 & 74.4 \\
\hline left pendant decoration wire & 1.5 & 21.0 & 77.3 \\
\hline left pendant suspension wire & 1.0 & 21.8 & 76.8 \\
\hline chencir chat & 1.4 & 20.2 & 78.2 \\
\hline suspension chain & 1.3 & 22.5 & 76.1 \\
\hline
\end{tabular}

Table 1: PIXE results obtained for the composition of the gold alloys used in the Kushan jewellery analysed (in \%).

Tableau 1 : Résultats obtenus par PIXE pour la composition des alliages utilisés dans la fabrication de l'orfevrerie kouchane (en \%).

quality. Among those objects, we draw attention to the pendant MK04.40.109, found in tomb V, and a gold appliqué MK04.40.113, found in tomb II (Collectif, 2006), dated to the $1^{\text {st }}$ century $\mathrm{AD}$, which contain on average $96 \% \mathrm{Au}$, $3 \% \mathrm{Ag}$ and $1 \% \mathrm{Cu}$, and $97 \% \mathrm{Au}, 1.8 \% \mathrm{Ag}$ and $1.1 \% \mathrm{Cu}$, respectively. An equivalent composition was obtained for the ingot dated from the $4^{\text {th }}-2^{\text {nd }}$ century $\mathrm{BC}$ found in the Palace of Al Khaouïn, a town founded by Alexander the Great and situated close to the present day Tajikistan border. 


\section{Conclusion}

The analytical study of five jewellery items containing gold wires and granules from the collections of the National Museum of Antiquities of Tajikistan provides a first approach to the goldsmiths' technological choices during the Kushan period. The non-destructive examination of the jewellery revealed the use of a large variety of techniques and decoration elements, sometimes very similar to those observed for the Afghani gold work of Tillya Tepe, such as the strip-twisted wires with seams running longitudinally along the wire, the absence of complex granulation patterns, the stone settings, the hammered elements, and so on.

The non-destructive analysis of the objects by PIXE revealed the use of two distinct gold alloys, which contain on average about $15 \% \mathrm{Ag}$ and $3 \% \mathrm{Cu}$ for one type of alloy (pendant 267) and 19-26\% Ag for the other (the other four objects), with copper contents that are either around $1 \%$ or around $2 \%$. Data on particular elements, such as wires and granules, cannot be generalized, but, if we exclude pendant 272 , we note that these elements have similar compositions to the other elements of one and the same item.

Our elemental results are distinct from the compositions obtained by several authors for a few items and an ingot from Tillya Tepe, for several items produced by the Xiongnu, for one Kushan pendant, and for most of the coins struck by the Kushans. Only the concave dinars struck under Vasudeva II show a composition similar to our objects.

We must note that the results obtained for these five objects cannot be generalized for Kushan jewellery, with technological traditions and skills that were influenced by Chinese, Iranian, Greek and Indian craftsmen. This combination of different traditions certainly also led to the use of many different alloys. In addition to this aspect, we must also bear in mind the diversity of the supplies in a region that benefited from contact with the trade routes between Orient and Occident.

\section{References}

Bunker, E.C., 1993. Gold in the Ancient Chinese World: A Cultural Puzzle. Asiae 53(1/2): 27-50.

Calligaro, T., 2006. Analyse des matériaux, in Collectif (eds.), Afghanistan, les trésors retrouvés: collections du musée national de Kaboul. Paris, Editions de la Réunion des musées nationaux, 292-293.

Catalogue, 1983. Shedevry Drevnego Iskusstva i Kul tury Tadzhikistana. Katalog vystavki (Art Treasures of Ancient Tajikistan. An exhibition
Catalogue). Materiali Yuzhno-Tajikistanskoi Arkheologicheskoi Ekspedichii.

Collectif (ed.), 2006. Afghanistan, les trésors retrouvés:_collections du musée national de Kaboul. Paris, Editions de la Réunion des musées nationaux.

Dani, A.H., LitVINSKI, B.A. and Zami SAFI, M.H., 1996. Eastern Kushans, Kidarites in Ghandara and Khasmi, and later Hephtalites, in B.A. Litvinski (ed.), History of civilizations of Central Asia Vol. 3, The crossroads of civilization: A.D. 250-750. Paris, Unesco, 163-184.

Drevnosti Tadzhikistana, 1985. Katalog vystavki (The antiquities of Tajikistan. An exhibit catalogue). Dushanbe, Tajikistan, Donish.

Fussman, G., 2003. L'empire Kouchan, in Musée de Lattes (ed.), De l'Indus à l'Oxus: Archéologie de l'Asie centrale. Catalogue de l'exposition. Exposition réalisée avec le concours exceptionnel de la bibliothèque nationale de France, département des monnaies, médailles et antiques. Lattes, Association Imago-Musée de Lattes, 171-210.

GuERRA, M.F., 2004. Fingerprinting ancient gold with proton beams of different energy. Nuclear Instruments and Methods in Physics Research B 226: 185-198.

GuERRA, M.F., 2008. An overview on the ancient goldsmith's skill and the circulation of gold in the past: the role of X-ray based techniques. X-ray Spectrometry 37(4): 317-327.

Guerra, M.F. and Calligaro, T., 2003. Analyse des éléments en or du site de Gol Mod, in J.-P. Desroches et al. (eds.), Mongolie le premier empire des steppes. Arles, Actes Sud/Grimaldi Forum/ Mission Archéologique française en Mongolie, 176-181.

Guerra, M.F. and Calligaro, T., 2004. Gold traces to trace gold. Journal of Archaeological Sciences 31: 1199-1208.

Guerra, M. F., Calligaro, T., Dran, J.-C., Moulherat, C. and Salomon, J., 2005. Development of a PIXE, PIGE and PIXEXRF combination for the analysis of the gold from the First Empire of the Steppes. Geoarchaeological and Bioarchaeological Studies 3: 343-346.

Mandelshtam, A.M., 1968. Pamyatniki epokci bronzi v yujnom Tadjikistane. Leningrad, Nauka.

Masov, R., Вовомulloev, S. and Bubnova, M. (eds.), 2005. National Museum of Antiquities of Tajikistan, Institute of History, Archaeology and Ethnography of the Academy of Sciences, National Museum of Antiquities. Dushanbe, Tajikistan, ActedBactria Cultural Center

Medvedskaya, I.N., Raskopki, V. and ShatrtuZe, V., 1975. Archaeologicheskie Raboty v Tajikistane: 15, 324-335.

Mukhamedjanov, A.R., 1994. Economy and social system in central Asia in the Kushan age. in J. Harmatta, B.N. Puri, G.F. Etemadi (eds.), History of civilizations of Central Asia Vol. 2, The development of sedentary and nomadic civilizations, 700 B.C. to A.D. 250. Paris, Unesco, 265-290. 
Ogden, J., 2007. Recovered Treasures from Afghanistan. American Journal of Archaeology 111(3): 559-563.

ODDY, A., 1977. The production of gold wire in Antiquity. Handmaking methods before the introduction of the draw-plate. Gold Bulletin 3(10): 79-87.

Puri, B.N., 1999. The Kushans, in J. Harmatta, B.N. Puri, G.F. Etemadi (eds.), History of civilizations of Central Asia Vol. 2, The development of sedentary and nomadic civilizations, 700 B.C. to A.D. 250. Paris, Unesco, 247-264

RapIN, C., 2007. Nomads and the shaping of central Asia: from the Early Iron Age to the Kushan period. Proceedings of the British Academy 133: 29-72.

Sachs, C., Blet-Lemarquand, M. and Gratuze, B., 2003. Médaillon avec monnaie Koushane sertie, in De l'Indus à l'Oxus: Archéologie de l'Asie centrale. Catalogue de l'exposition. Exposition réalisée avec le concours exceptionnel de la bibliothèque nationale de France, département des monnaies, médailles et antiques. Lattes, Association Imago-Musée de Lattes, 189-190.

SARIANIDI, V., 1980. The Treasure of Golden Hill. American Journal of Archaeology 84(2): 125-131.

Sarkhosh Curtis, V. and Stewart, S., 2007. The age of the Parthians, The Idea of Iran Vol. 2. London, Middle East Institute.

SEDov, A.V., 1979. Raskopki kurganov i poselenii v Beshkentskoi doline. Archeologicheskie Otkrytiya 1978: 584-585.

Thorley, J., 1971. The Silk Trade between China and the Roman Empire at Its Height, 'Circa' A.D. 90-130. Greece \& Rome II 18(1): 71-80.

Vitobello, M.L., Guerra, M.F., Mirsaidov, L.U. and Bовомulloev, S.G., 2009. Scientific Characterization of Tajikistan Golden Artefacts. Dushanbe, Tajikistan, Delta Print.

WooD, F., 2002. The Silk Road: Two Thousand Years in the Heart of Asia. Berkeley, University of California Press. 
